\title{
Opportunities to Target T Cell Trafficking in Pediatric Inflammatory Bowel Disease
}

\author{
Eirini Giannoudaki ${ }^{1,2+}$, Siobhan Gargan ${ }^{1,2+}$, Seamus Hussey ${ }^{1,3}$, Aideen Long ${ }^{1,2+}$ and \\ Patrick T. Walsh ${ }^{1,2 \star \neq}$ \\ ${ }^{1}$ National Children's Research Center, Children's Health Ireland (CHI) Crumlin, Dublin, Ireland, ${ }^{2}$ Trinity Translational Medicine \\ Institute, Trinity College Dublin, Dublin, Ireland, ${ }^{3}$ Department of Paediatrics, Royal College of Surgeons of Ireland, Dublin, \\ Ireland
}

OPEN ACCESS

Edited by:

Consolato Sergi,

University of Alberta Hospital, Canada

Reviewed by:

Helen Michelle McGettrick, University of Birmingham, United Kingdom

Corentin Babakissa

Université de Sherbrooke, Canada

*Correspondence:

Patrick T. Walsh

walshp10@tcd.ie

tThese authors have contributed equally to this work and share first authorship

¥These authors have contributed equally to this work and share senior authorship

Specialty section: This article was submitted to Pediatric Gastroenterology, Hepatology and Nutrition, a section of the journal Frontiers in Pediatrics

Received: 11 December 2020 Accepted: 08 February 2021 Published: 18 March 2021

Citation: Giannoudaki E, Gargan S, Hussey S, Long A and Walsh PT (2021) Opportunities to Target T Cell Trafficking in Pediatric Inflammatory

Bowel Disease.

Front. Pediatr. 9:640497.

doi: 10.3389/fped.2021.640497
T cell subsets are considered central orchestrators of inflammation and homeostasis in the intestine and are established targets for the treatment of inflammatory bowel disease. While approaches aimed at the neutralization of $T$ cell effector cytokines have provided significant benefits for pediatric and adult patients, more recent strategies aimed at inhibiting the infiltration of pathogenic $T$ cell subsets have also emerged. In this review, we describe current knowledge surrounding the function of $T$ cell subsets in pediatric inflammatory bowel disease and outline approaches aimed at targeting $T$ cell trafficking to the intestine which may represent a new treatment option for pediatric inflammatory bowel disease.

Keywords: inflammatory bowel disease, Crohn's disease, ulcerative colitis, pediatric, T cell trafficking, infiltration

\section{INTRODUCTION}

Inflammatory Bowel Disease (IBD) is a heterogeneous autoimmune disorder characterized by chronic and relapsing inflammation of the gastrointestinal (GI) tract. The two main subtypes of IBD are Crohn's Disease (CD) and Ulcerative Colitis (UC) (1). Around 20\% of IBD cases are diagnosed during childhood, mainly during adolescence (2). IBD disease phenotype and natural history differ depending on the age of onset (3). Pediatric (P)IBD can be subdivided into early onset (EO) IBD diagnosed after the age of 10 , very early onset (VEO) IBD diagnosed under age 10 and infantile IBD diagnosed under the age of 1 (4). The global incidence of PIBD, primarily CD, is rising and CD is currently the most common form of $\operatorname{PIBD}(5,6)$. Studies from countries including Ireland (7), Scotland (8), and Spain (9) have shown increased PIBD cases over time. The prevalence of PIBD is higher in western populations and highest in North America and Europe (10). The "hygiene hypothesis" suggests that lack of exposure to microbial infections in early life increases the risk of developing CD (11-13). Genetic susceptibility (with susceptibility loci in genes encoding mediators of the immune response to microbes such as IL23R and NOD2), environmental factors (such as childhood infections) and the gut microbiome all contribute toward the development of PIBD (14-16). Breast feeding can decrease the risk of PIBD (17) while exposure to antibiotics during pregnancy increases the risk of VEO-IBD (18), likely due to changes in the microbiota (19).

Compared with adult onset IBD, PIBD is associated with early progression rates. Pediatric UC is associated with more severe colitis at onset (20) and CD displays a more panenteric phenotype during adolescence, with upper GI symptoms more common (21). No curative treatment exists but current treatments [including exclusive enteral nutrition (EEN)] aim to improve the quality of life, mitigate the psychosocial effects and reduce the need for surgery $(22,23)$. Common IBD symptoms include diarrhea, abdominal pain and weight loss (2) but PIBD can lead to 
further complications such as height impairment, malnutrition, anemia and delayed puberty (24). Delayed treatment increases the risk of growth-related defects $(25,26)$ while prolonged treatment with immunosuppressive therapies increases the risk of opportunistic infection (27). In addition, population studies have revealed higher mortality rates in patients with pediatric onset IBD compared with the general population due to the occurrence of colorectal cancer and infections (28-32). This highlights the potential benefit of novel, more specific therapies for PIBD. Similar to the more extensively studied adult disease, PIBD is characterized by a dysregulated inflammatory response to bacteria in the gut and subsequent activation and infiltration of $\mathrm{T}$ cells. This review will discuss the role of $\mathrm{T}$ cells in the pathogenesis of PIBD, the mechanism of T cell trafficking to the gut and the opportunity to target $\mathrm{T}$ cell migration as a treatment for PIBD.

\section{CD4+ T HELPER CELL SUBSETS IN THE CHRONICALLY INFLAMED INTESTINE}

In the healthy gut discrimination between pathogenic and commensal bacteria is achieved through interaction between epithelial and immune cells in the gut-associated lymphoid tissue (GALT) where specialized epithelial M (microfold) cells deliver antigens to underlying lymphoid follicles (LFs) (33). In the small intestine, LFs group together to form Peyer's Patches (PPs) which increase in number with age, peaking at puberty (34). Antigen presenting cells (APCs) such as Dendritic Cells (DCs) in PPs and LFs uptake antigens from the gut lumen and migrate to the mesenteric lymph nodes (MLN) where they initiate $\mathrm{T}$ cell responses (33). In the healthy gut, DCs preferentially promote regulatory $\mathrm{T}$ cell (Treg) responses which contribute to intestinal immune tolerance and homeostasis through the production of anti-inflammatory cytokines such as IL-10 and TGF- $\beta$ (35).

In PIBD dysbiosis leads to pathogenic $\mathrm{T}$ helper type 1 (Th1), Th2, Th9, and Th17 cell responses and an imbalance of Treg cells. Forkhead box P3 (FOXP3) + Treg cells play an essential role in intestinal tolerance and gut homeostasis (36). The importance of the FOXP3 transcription factor is highlighted by Immunodysregulation Polyendocrinopathy Enteropathy Xlinked (IPEX) syndrome, a rare disease caused by mutations in the gene encoding FOXP3 which results in severe autoimmunity and intestinal disease at infancy and early fatality due to the loss of Treg cells (37-39). This phenotype has been attributed to a dysfunction in Treg subsets which are critical toward maintaining immune tolerance in the gut. Along these lines, decreased levels of FOXP3 + Treg cells have also been reported in peripheral blood from patients with mild, moderate and inactive PIBD (40). Separately, decreased levels of FOXP3 + Treg cells were found in the colonic Lamina Propria (LP) of pediatric CD patients compared to healthy controls, though these decreased levels were reversed upon treatment with the TNF- $\alpha$ inhibitor infliximab (41).

However, several studies have also reported contrasting results showing increased levels of FOXP3 + Treg cells in the intestinal LP of pediatric CD patients $(42,43)$. Increased FOXP3+ Treg cells were found to occur in association with elevated levels of TGF- $\beta 1$, suggesting that they maintain their anti-inflammatory phenotype (42). Higher levels of FOXP3+ Treg cells were also found in the ileal mucosa of pediatric CD patients when compared with adult CD patients and significantly higher levels of FOXP3+ Treg cells were found in the ileum and colon of treatment naïve pediatric CD patients compared with healthy controls (44). In addition, higher levels of FOXP3+ Treg cells have also been demonstrated in the peripheral blood, as well as the inflamed intestinal mucosa of PIBD patients $(45,46)$. Interestingly, levels of FOXP3 + cells were reported to be reduced in the intestinal mucosa of PIBD patients in remission when compared to those with active disease, although the levels of circulating Tregs remained elevated (45). Overall, these studies suggest that intestinal levels of FOXP3 + cells are most elevated during active PIBD but are modulated upon treatment.

Although such elevated levels of Tregs might be expected to exert a more profound immunosuppressive effect in the inflamed PIBD intestine, it remains to be fully determined whether the function of these cells is intact, and if not, whether this may contribute to disease pathology. The precise and complex role of FOXP3+ Tregs in the context of PIBD remains to be fully uncovered. In particular, whether these cells can play an important role in restricting pathogenic inflammation and/or promoting homeostasis and resolution will be important. Of interest in this regard, and pointing to the importance of intact Treg function, is the observation that gut homing $\mathrm{CD} 4+$ Treg cells express high levels of retinoic acid inducible $\mathrm{CD} 38$ and the co-inhibitory receptor T-cell immunoglobulin and Immunoreceptor Tyrosine-based Inhibition Motif (ITIM) domain (TIGIT) (47). In PIBD, loss of TIGIT expressing CD38 $+\mathrm{T}$ cells in peripheral blood was found to correlate with shorter remission periods (47). Furthermore, other FOXP3-ve Treg subsets may also play significant roles. IL-27, which induces the differentiation of naïve $\mathrm{CD} 4+\mathrm{T}$ cells into Type 1 regulatory $\mathrm{T}$ cells $(\mathrm{Tr} 1)$ cells, is encoded in a susceptibility locus for EO IBD (48, 49).

It has been suggested that the loss of balance between antiinflammatory FOXP3 + Treg cells and pro-inflammatory IL-17A expressing T cells (Th17 cells) can contribute to the pathogenesis of IBD (50). The pathogenic role of Th17 cells in gut homeostasis and inflammation is complex. Although originally considered pathogenic in nature, clinical trials evaluating specific strategies aimed at IL-17A neutralization in adult CD patients were found to result in a worsening of disease outcomes, at least in some patients (51). Notwithstanding these observations, a recent study showed an increase in Th17 cells in peripheral blood from patients with PIBD which was attributed to increased serum levels of the Th17-inducing pro-inflammatory cytokines IL-23 and IL-6 (40). Interestingly, one study showed higher serum levels of Th17 signature cytokines IL-17A and IL-22 in pediatric patients with UC compared to those with CD (43) while another study showed upregulation of IL-17A and IL-22 mRNA in the colon of patients with both UC and CD when compared with healthy controls (46). Furthermore, a recent study showed significantly higher serum levels of IL-17A in PIBD patients 
compared with controls (52). These studies suggest a pathogenic role for Th17 cells in PIBD.

In addition to more recent analyses of Treg and Th17 subsets, earlier studies focused on characterizing the influence of Th1 vs. Th2 responses in the pathogenesis of PIBD. Based upon observations in adult patients, $\mathrm{CD}$ has classically been characterized as being associated with elevated Th1 type responses, whereas UC is associated with an "atypical" Th2 type response $(53,54)$. While early reports indicated that a similar dichotomy could be observed in PIBD patients $(55,56)$, a more complex picture has since emerged. For example, the Th2 transcription factor GATA-3 and the Th1 signaling molecule signal transducer and activator of transcription (STAT) 4 were found to be significantly upregulated in the mucosa of patients with UC, highlighting the possible importance of both Th1 and Th2 subsets in the pathogenesis of pediatric UC (57). In contrast, it has also been reported that levels of expression of IFN- $\gamma$ were reduced in the peripheral blood of newly diagnosed pediatric CD patients (58). While such reports highlight a lack of clarity concerning the relative contribution of distinct $\mathrm{T}$ subsets toward the pathogenesis of PIBD, it is also noteworthy that the frequency at which Th subsets can be detected changes dramatically with age especially during childhood $(59,60)$.

While most data concerning the nature of Th responses in the context of PIBD have focused on the subsets described above, there is also mounting evidence that less well-characterized subsets may play important roles. For example, CD4+ effector T cell subsets expressing high levels of IL-9 (Th9 cells) have also emerged as potential important players in the pathogenesis of adult UC and in preclinical models of disease (61). However, whether this subset plays a significant role in the pathogenesis of pediatric UC remains to be determined.

\section{OTHER T CELL SUBSETS IN THE CHRONICALLY INFLAMED INTESTINE}

As well as the CD4+ $\mathrm{T}$ helper cell subsets described above, several other immune cell subsets have been reported to influence the balance between $\mathrm{T}$ cell tolerance and inflammation in the intestine. Group 3 Innate lymphoid cells (ILC3s) have been shown to specifically induce the destruction of activated commensal bacteria specific $\mathrm{T}$ cells (62). However, the expression of major histocompatibility complex (MHC) class II was found to be lower in ILC3 cells from patients with PIBD which could contribute toward the dysregulation of $\mathrm{T}$ cell responses and gut homeostasis (62). PIBD patients were also found to have fewer CD39 expressing intraepithelial CD8+ memory T cells and $\gamma \delta$ T cells compared with non-IBD controls (63). CD39 degrades excessive extracellular ATP and helps maintain gut homeostasis (63). Pediatric patients with newly diagnosed UC but not CD were found to have higher circulating levels of activated CD4+ and CD8+ T lymphocytes expressing $\beta 1$ integrin, correlating with biomarkers of mucosal and systemic inflammation (64). In addition, a further study demonstrated decreased $\mathrm{V} \delta 2+\mathrm{T}$ cells in the peripheral blood of pediatric CD patients, but an increased infiltrate of integrin $\beta 7$ expressing V $\delta 2+\mathrm{T}$ cells in the colon, which exacerbated inflammation through the release of TNF- $\alpha$ (65). Such studies highlight the potential therapeutic benefit of inhibiting pathogenic $\mathrm{T}$ cell trafficking to the gut.

The orchestrating role of different $\mathrm{T}$ cell subsets in mediating inflammation and homeostasis in the intestine underlines their potential as therapeutic targets in IBD. Further investigation into the specific roles of $\mathrm{T}$ cell subsets, beyond $\mathrm{CD} 4+\mathrm{T}$ helper subsets, in UC and CD may optimize this therapeutic potential. In particular, efforts aimed at restricting the ability of pathogenic $T$ cell subsets to traffic to and infiltrate intestinal tissues is an area of intense investigation.

\section{MECHANISMS OF T CELL TRAFFICKING}

Whether gut resident $\mathrm{T}$ cells play instructive roles in homeostasis or inflammation, they must first home specifically to the intestinal tissues. In order for lymphocytes to travel through the endothelium into a specific tissue, they undergo three main steps: rolling, adhesion and trans-migration or diapedesis. Rolling is mediated by selectins and supported by integrins, whereas integrins mainly facilitate firm adhesion and diapedesis. Chemokine signaling is also important to guide the cells toward the tissue and activate their adhesion molecules (66).

For trafficking to the gut, initially, naïve $\mathrm{T}$ cells have to travel from the blood to GALT and MLN. GALT consists of the inductive sites of the intestinal tissue, mainly PPs and isolated lymphoid follicles (ILF) (67). Both GALT and MLN are associated with high endothelial venules (HEV) through which the T cells travel. HEV express mucosal addressin cell adhesion molecule1 (MAdCAM-1) and peripheral node addressin (PNAd), which bind to L-selectin expressed on the T-cell surface (68-72) (Figure 1A). This allows tethering and rolling of the cells on the endothelial surface, which is then followed by firm adhesion, by binding of integrins $\alpha_{4} \beta_{7}$ and lymphocyte functionassociated antigen-1 (LFA-1; CD11a/CD18; $\alpha_{\mathrm{L}} \beta_{2}$ ) on the T-cell surface to their ligands on the endothelial cells, MAdCAM-1 and intercellular adhesion molecule-1 (ICAM-1), respectively (69). To promote this adhesion, integrins are activated by inside-out signaling via chemokine receptors, specifically CCL21 and CXCL12 binding chemokine receptors CCR7 and CXCR4, respectively, on T-cells. Firm adhesion is followed by transendothelial migration into the lymphoid tissue $(69,71,73,74)$.

The naïve T cells that enter the MLN and GALT become activated into colitogenic effector T cells, such as Th1 and Th17, but they also obtain a "gut homing" phenotype. This phenotype is characterized by upregulated adhesion molecules and chemokine receptors, especially $\alpha_{4} \beta_{7}$ and CCR9, which bind to MAdCAM1 and CCL25, respectively, on GALT and $\alpha_{4} \beta_{1}$ and CXCR3, which bind to VCAM-1 and CXCL10 on activated endothelium (73-75). Upon entering GALT or MLN, lymphocytes encounter antigen through DCs, causing their polarization into effector cells and imprinting the gut homing phenotype (Figure 1A). A specific DC subset, which is CD103+, appears to be significant for this interaction and subsequent imprinting of the gut homing phenotype $(76,77)$. CD103+ DCs are derived from intestinal LP, and they express high levels of Aldh1a2, a gene encoding 


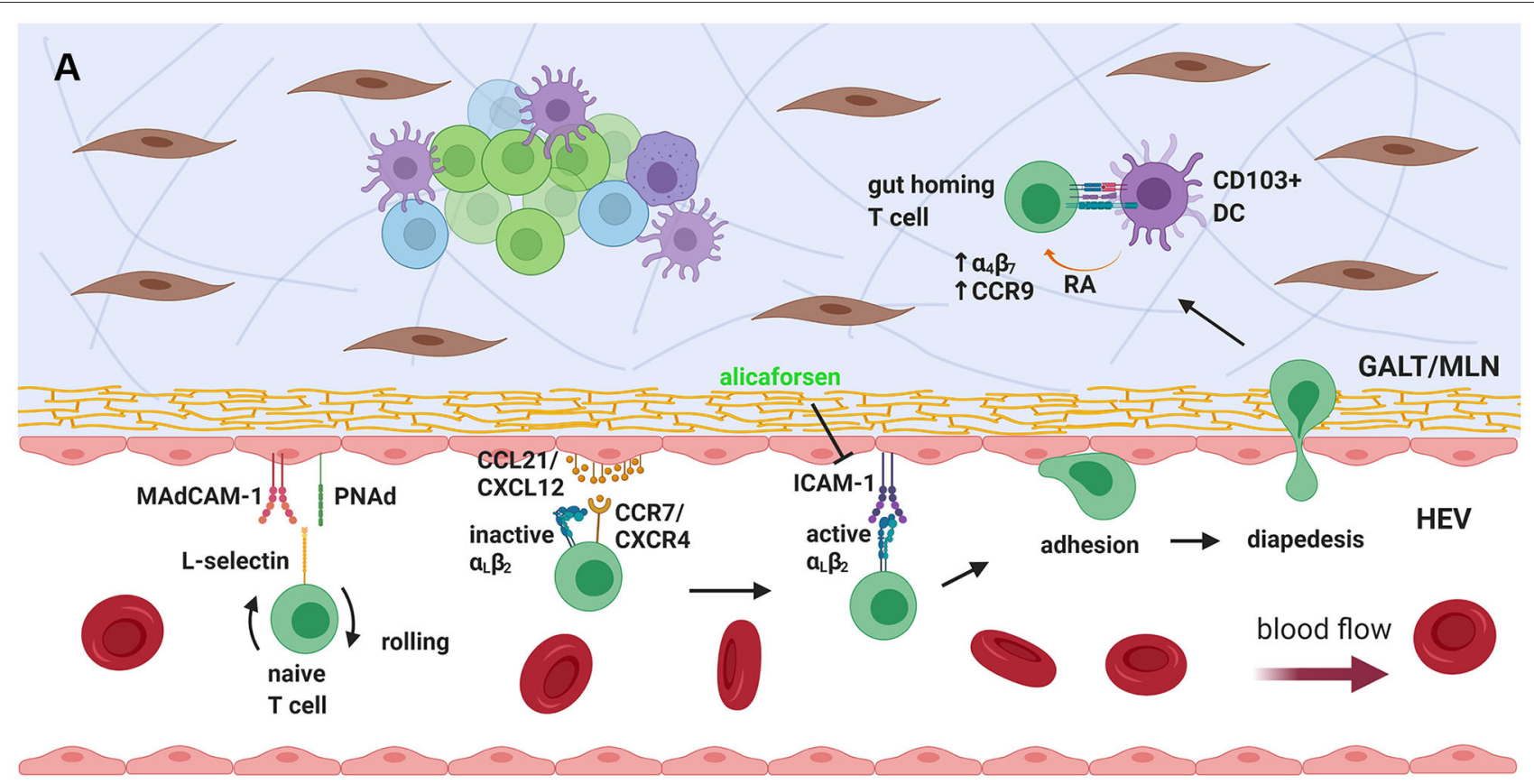

B

lumen

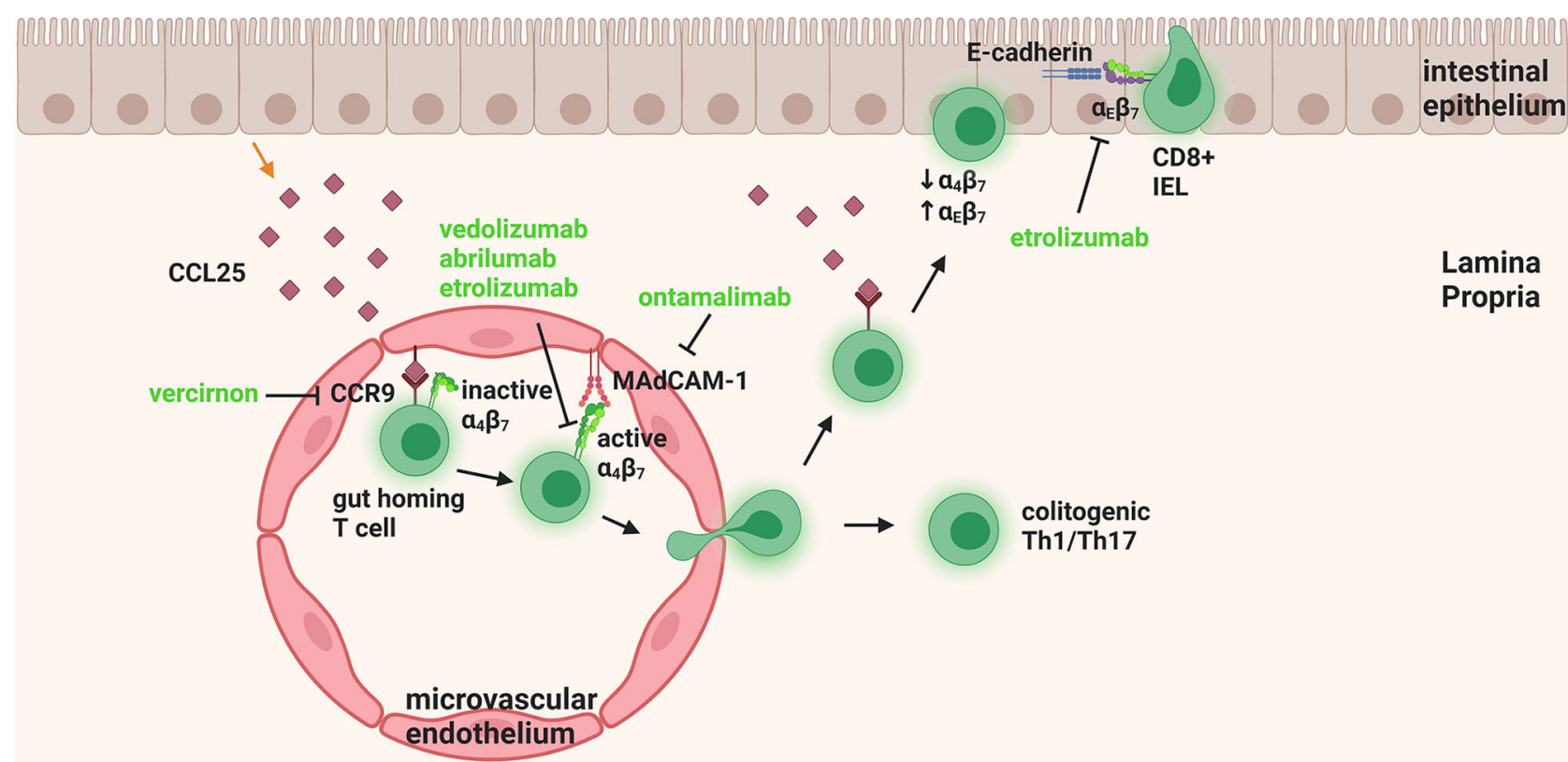

FIGURE 1 | Naiive T-cell trafficking to GALT/MLN and gut homing T cell trafficking to LP and epithelium. (A) Naïve T-cells in the HEV need to undergo rolling, by interaction of L-selectin on their surface with MAdCAM-1 and PNAd on the endothelial cells. Binding of chemokines CCL21/CXCL12 to the chemokine receptors CCR7/CXCR4 activates $\alpha\llcorner\beta 2$ integrin to bind to ICAM-1, leading to firm adhesion and diapedesis. When inside the GALT/MLN, the T-cell interacts with DCs that produce RA, to upregulate $\alpha_{4} \beta_{7}$ and CCR9, giving it a "gut homing" phenotype. (B) The gut-homing T cell expresses CCR9, which binds to CCL25, produced by epithelial cells and anchored to microvascular endothelium. This causes the activation of $\alpha 4 \beta 7$ integrin, which binds to MAdCAM-1, leading to trans-migration of the T cell to intestinal LP. There it can stay, as a colitogenic Th1/Th17 cell, or move, again through CCR9-CCL25 interactions, toward the epithelium, where it downregulates 
FIGURE $1 \mid \alpha_{4} \beta_{7}$ and upregulates $\alpha_{E} \beta_{7}$, which binds to epithelial E-cadherin. The T cell then resides in the epithelial layer as a CD8+ IEL. Therapeutic targeting can be seen in green. GALT, Gut-associated lymphoid tissue; MLN, mesenteric lymph node; HEV, high endothelial venule; MAdCAM-1, mucosal addressin cell adhesion molecule-1; PNAd, peripheral node addressin; ICAM-1, intercellular adhesion molecule-1; DC, dendritic cell; RA, retinoic acid; IEL, intraepithelial lymphocyte. Figure created with Biorender.com.

an isoform of retinaldehyde dehydrogenase (RALDH), which is mediator of the metabolic pathway converting vitamin A into retinoic acid (RA) (76-79).

Retinoic acid has been shown to be important for gut homing imprinting of both T and B lymphocytes, by upregulating $\alpha_{4} \beta_{7}$ and CCR9 molecules $(80,81)$. Vitamin A deficiency results in a significant decrease in $\alpha_{4} \beta_{7}+\mathrm{T}$ cells in lymphoid organs and depletion of $\mathrm{T}$ cells from the small intestinal LP (80). Intestinal DCs and epithelial cells produce RA, which binds and signals through RA receptor-retinoid $\mathrm{X}$ receptor heterodimers expressed by recruited $\mathrm{T}$ and $\mathrm{B}$ cells $(78,79,82)$. The RA receptor complex acts as transcription factor (78) contributing to the "gut homing" phenotype of GALT lymphocytes $(80,81)$. These B cells will then be activated into antibody producing plasma cells, which will undergo class switching into IgA producing cells in an RA dependent manner, and will reside in the intestinal mucosa (79, 81, 83). Gut tropism can be inhibited by LE540, a small molecule that blocks RA binding to RA receptor (81). FoxP3+ natural regulatory T cells (nTreg) can also be induced into a gut-homing phenotype in the MLN, further suggesting that in the steady state there is a balance of regulatory vs. effector $\mathrm{T}$ cells that might be disrupted in pathogenic conditions such as during $\operatorname{IBD}(84,85)$. However, in adoptive transfer models of colitis, molecules such as L-selectin and CCR7, which allow homing to MLNs and GALT, seemed to be more important for Treg suppressive abilities than LP gut homing molecules, such as $\beta_{7}$ integrin (86-88).

The gut-homing effector $\mathrm{T}$ cells re-enter the circulation and travel to the small intestine LP by binding to CCL25, mainly secreted by small intestine epithelial cells and anchored to the cell surface of LP microvascular endothelial cells. This in turn promotes activation of $\alpha_{4} \beta_{7}$ for firm adhesion to MAdCAM-1 and migration to LP $(69,71-73)$. MAdCAM-1 is constitutively expressed by gut associated endothelium; however, its expression is upregulated in inflamed LP venules during both CD and UC (89). Some gut lymphocytes, mainly CD8 + T cells in the murine small intestine, reside inside the intestinal epithelial layer instead of the LP, and are termed intraepithelial lymphocytes (IEL). IEL need to further travel through the LP and the basal membrane to the intestinal epithelium, a process similarly mediated by CCR9 and CCL25 chemokine signaling $(70,90,91)$. When IEL enter the epithelium, they downregulate $\alpha_{4} \beta_{7}$ and upregulate $\alpha_{E} \beta_{7}$, which binds to E-cadherin on intestinal epithelial cells, anchoring them to the epithelium (90) (Figure 1B). CCR9/CCL25 expression mediates rapid induction of $\alpha_{E} \beta_{7}$ in murine CD8+ IEL and adhesion to E-cadherin (90).

Less is known on the mechanism of immune cell trafficking to the colon, compared to the small intestine. Activated CD8+ $\mathrm{T}$ cells required $\alpha_{4} \beta_{7}$ to enter the colonic mucosa, but not CCR9, whereas CCL25 is expressed in very low levels in normal colon (92-94). On the other hand, blocking the CXCR4/CXCL12 chemokine signaling axis, inhibited lymphocyte adhesion to the colon as well as the small intestine (95). Moreover, vitamin A deficiency only reduced migration to the small intestine, not the colon, in a mesenteric lymphoblast transfer in rats, indicating RA is not required for "colon homing" (96). The orphan receptor GPR15 has been identified as a colon-homing receptor for human and murine effector CD4+ T cells, but not human Treg, making it a potentially attractive target for colitis intervention $(97,98)$. Expression of GPR15 is altered in UC, where it is enhanced in non-inflamed biopsies from UC patients when compared to inflamed biopsies (99). In contrast, CCL25 is upregulated in the inflamed colon of UC patients, and most infiltrating effector $\mathrm{T}$ cells (90\%) in the inflamed tissue are CCR9+ compared to $<10 \%$ in normal colon (100). This might indicate there is a shift in $\mathrm{T}$ cell chemokine receptor expression during active colitis, from GPR15 to CCR9 expression. In a mouse model of acute colitis, CCR9/CCL25 are upregulated in the colon, and play a regulatory role by controlling DC subsets balance (101).

Deficiency of $\beta_{7}$ integrin in mice or antibody blockade of $\alpha_{4} \beta_{7}$ or MAdCAM-1 molecules, severely impairs lymphocyte trafficking to GALT and intestine and ameliorates disease pathology in a mouse model of CD-like chronic ileitis (102104). Although CCR9/CCL25 signaling is seemingly important for $\mathrm{T}$ cell trafficking to small intestinal LP, mice lacking any of these molecules have almost normal numbers of LP T cells, suggesting other mechanisms are in place to facilitate gut immune cell migration in the absence of this chemokine axis (105). Location appears to be an important determinant as to whether CCR9 plays a major role or not, as shown by competitive adoptive transfer experiments using both wild type and CCR9-/- $\alpha_{4} \beta_{7}+\mathrm{T}$ cells. These cells were more dependent on CCR9 for entry to the intestinal epithelium than the LP and in the proximal rather than the distal small intestine (94). Other chemokine receptor/chemokine pairs that are potentially important in recruiting $\mathrm{T}$ cells to the inflamed LP include CXCR3/CXCL10, CXCR4/CXCL12 and CCR6/CCL20 $(95,106)$. The expression of CXCR3 and its ligands CXCL9, CXCL10, and CXCL11 is upregulated in the inflamed colon of patients with PIBD (107). Blocking of CXCR4/CXCL12 axis reduced adherence of LP lymphocytes to intestinal microvessels, as shown by intravital microscopy in mice, in both normal conditions and during TNF- $\alpha$ induced inflammation, whereas blocking of CXCR6/CCL20 axis only affected adherence in inflamed tissue (95). CCL20 is upregulated in colon tissue of IBD patients and mice after DSS-colitis $(108,109)$.

\section{STRATEGIES TO TARGET T CELL TRAFFICKING}

Therapeutic approaches in PIBD are for the most part aimed at alleviating symptoms to facilitate healthier growth and 
TABLE 1 | Drugs targeting lymphocyte trafficking currently under clinical trial.

\begin{tabular}{|c|c|c|c|c|}
\hline Drug & Target & Phase & Indication & Outcomes \\
\hline Abrilumab (AMG181) & $\begin{array}{l}\text { Antibody against } \alpha_{4} \beta_{7} \\
\text { integrin }\end{array}$ & 2 & UC and CD & $\begin{array}{l}\text { Positive outcomes, } \\
\text { particularly for UC }\end{array}$ \\
\hline AJM300 & Oral $\alpha_{4}$ integrin antagonist & 3 & UC & Phase 2 trial in UC positive \\
\hline TRK-170 & Oral $\alpha_{4}$ integrin antagonist & 2 & $C D$ & Unknown \\
\hline Firategrast (SB 683699) & Oral $\alpha_{4}$ integrin antagonist & 2 & $\mathrm{CD}$ & Unknown \\
\hline Etrolizumab (rhuMAb Beta7) & Antibody against $\beta_{7}$ integrin & 3,1 for PIBD & UC and CD, PIBD & $\begin{array}{l}\text { UC results disappointing, } \\
\text { some UC trials terminated }\end{array}$ \\
\hline Alicaforsen (ISIS-2302) & ICAM-1 antisense inhibitor & 2 & UC and CD & Limited efficacy \\
\hline $\begin{array}{l}\text { Vercirnon (GSK1605786; } \\
\text { CCX282-B; Traficet-EN) }\end{array}$ & Oral CCR9 antagonist & 3 & $C D$ & Limited efficacy \\
\hline $\begin{array}{l}\text { Ontamalimab (PF- } \\
\text { 00547659; SHP647) }\end{array}$ & Antibody to MAdCAM-1 & 3 & UC and CD & $\begin{array}{l}\text { Promising results in phase } 2 \\
\text { trial in UC }\end{array}$ \\
\hline Ozanimod (RPC1063) & Oral S1PR1 and 5 agonist & 3 & UC and CD & $\begin{array}{l}\text { Preliminary results in UC } \\
\text { positive }\end{array}$ \\
\hline
\end{tabular}

development, while minimizing drug adverse effects, to improve quality of life for patients (110). Generally, the guidelines for the use of drugs in pediatric patients are based on adult studies, however, the pharmacokinetics and pharmacodynamics of drugs in children are different and doses have to be adjusted accordingly, for each child $(111,112)$. The therapeutic strategy for PIBD is to start gradually, with enteral nutrition intervention, and/or corticosteroid administration to achieve remission. However, in severe cases, more aggressive approaches are recommended, to induce mucosal healing and enter a state of "deep remission." These approaches include immunomodulatory drugs, such as azathioprine and methotrexate (MTX), as well as biologics, mainly TNF- $\alpha$ inhibitors, and most commonly infliximab and adalimumab (113).

While the successful use of TNF- $\alpha$ inhibitors may impact $\mathrm{T}$ cell infiltration to the inflamed gut (114), there are currently two drugs in the clinic that specifically target immune cell trafficking approved for use in adult patients with IBD. These are both monoclonal antibodies designed to block integrins (Figure 1B). Natalizumab is a monoclonal antibody against $\alpha_{4}$ integrin subunit, and targets both $\alpha_{4} \beta_{7}$ and $\alpha_{4} \beta_{1}$ adhesion molecules. Although it can block lymphocyte trafficking to the gut, it also affects lymphocyte trafficking to the central nervous system, mediated by $\alpha_{4} \beta_{1}$ integrin (115). As a result, natalizumab administration poses a risk of progressive multifocal leukoencephalopathy, caused by reactivation of the John Cunningham (JC) virus, for which $67.5 \%$ of adults with $\mathrm{CD}$ were seropositive, in range with the general population (116). On the other hand, vedolizumab poses no such risk, since it specifically targets the $\alpha_{4} \beta_{7}$ integrin, with its effects on lymphocyte trafficking being limited to the gut (117). As such, vedolizumab demonstrates an excellent safety profile for use in IBD, with low rates of serious infections, malignancies and other adverse reactions (118). However, to date neither of these two agents have received regulatory approval for pediatric use, although they have been used off-label, and there have been limited reports on their successful use in PIBD $(119,120)$. Vedolizumab in particular, was more effective in pediatric UC than $C D$, and in anti-TNF treatment naïve patients, rather than those previously treated with TNF inhibitors (120). Currently, vedolizumab is mainly administered after failure of TNF- $\alpha$ antagonists, but these data strongly suggest it should be considered as a first line treatment for PIBD (121).

As well as the two approaches described above, a number of other strategies aimed at targeting $\mathrm{T}$ cell trafficking are also under clinical investigation (Figure 1; Table 1). Similar to vedolizumab, a second anti-integrin $\alpha_{4} \beta_{7}$ blocking antibody, abrilumab, has undergone phase 2 trials in both UC and $\mathrm{CD}$, with some positive outcomes $(122,123)$. Other small molecule antagonists of the $\alpha_{4}$ integrin subunit, AJM300, TRK170 and Firategrast, have also undergone clinical study among adult IBD patient cohorts. A further approach currently under clinical investigation in IBD is etrolizumab (rhuMAb Beta7), a monoclonal antibody against the $\beta_{7}$ integrin subunit, which blocks lymphocyte trafficking to the gut, mediated by $\alpha_{4} \beta_{7}$ integrin, and retention of IEL on the enteric epithelium, mediated by $\alpha_{E} \beta_{7}$ (124). Etrolizumab has shown very promising results in phase 1 and 2 clinical trials for $\operatorname{UC}(125,126)$ and is currently on phase 3 clinical trials for both UC and CD. However, results for UC have been disappointing thus far. Significantly, etrolizumab is currently under investigation in phase 1 clinical trial in pediatric IBD patients, to assess pharmacokinetics, pharmacodynamics and safety (NCT03478956). Other molecules developed include an ICAM-1 adhesion molecule antisense blocking agent, alicaforsen (ISIS-2302) and an orally bioavailable CCR9 antagonist, vercirnon (GSK1605786; CCX282-B; Traficet$\mathrm{EN})$. Alicaforsen underwent phase 2 clinical trials in both UC and CD, with limited efficacy $(127,128)$, whereas vercirnon was in phase 3 clinical trials in $\mathrm{CD}$, but failed to demonstrate efficacy (129, 130). An antibody targeting MAdCAM-1 is also being investigated, ontamalimab (PF- 00547659; SHP647), with promising phase 2 trials in UC, that is currently under phase 3 trials in both UC and CD (131). Finally, an oral sphingosine 1-phosphate receptor (S1PR) 1 and 5 agonist, ozanimod (RPC1063), has undergone phase 2 clinical trials in $\mathrm{UC}$ and $\mathrm{CD}$ and phase 3 trials are currently 
recruiting patients for moderate to severe $\mathrm{UC}$ and $\mathrm{CD}$. Ozanimod is an S1PR agonist that can cause sequestration of lymphocytes into the secondary lymphoid organs and subsequent reduction of migrated lymphocytes in the gut and other organs, that is currently approved for treatment of multiple sclerosis (132).

In conclusion, targeting of lymphocyte trafficking to the gut may represent a very promising novel therapeutic approach for PIBD, with fewer adverse effects than general immunomodulatory and anti-TNF therapies, due to its more selective nature. Targeting of adhesion molecules has been extensively studied in the clinic, with demonstrated efficacy among adult patients and further promising new agents currently in development. Other targets, such as chemokine receptors and S1PR, are also available, but further study is warranted to prove their efficacy and safety. While the overwhelming majority of

\section{REFERENCES}

1. Silverberg MS, Satsangi J, Ahmad T, Arnott ID, Bernstein CN, Brant SR, et al. Toward an integrated clinical, molecular and serological classification of inflammatory bowel disease: report of a Working Party of the 2005 Montreal World Congress of Gastroenterology. Can J Gastroenterol. (2005) 19(Suppl. A):5a-36a. doi: 10.1155/2005/269076

2. Rosen MJ, Dhawan A, Saeed SA. Inflammatory bowel disease in children and adolescents. JAMA Pediatr. (2015) 169:105360. doi: 10.1001/jamapediatrics.2015.1982

3. Ruel J, Ruane D, Mehandru S, Gower-Rousseau C, Colombel JF. IBD across the age spectrum: is it the same disease? Nat Rev Gastroenterol Hepatol. (2014) 11:88-98. doi: 10.1038/nrgastro.2013.240

4. Almana Y, Mohammed R. Current concepts in pediatric inflammatory bowel disease; IL10/IL10R colitis as a model disease. Int J Pediatr Adolesc Med. (2019) 6:1-5. doi: 10.1016/j.ijpam.2019.02.002

5. Benchimol EI, Fortinsky KJ, Gozdyra P, Van den Heuvel M, Van Limbergen J, Griffiths AM. Epidemiology of pediatric inflammatory bowel disease: a systematic review of international trends. Inflamm Bowel Dis. (2011) 17:42339. doi: 10.1002/ibd.21349

6. Sykora J, Pomahacova R, Kreslova M, Cvalinova D, Stych P, Schwarz J. Current global trends in the incidence of pediatriconset inflammatory bowel disease. World J Gastroenterol. (2018) 24:2741-63. doi: 10.3748/wjg.v24.i25.2741

7. Hope B, Shahdadpuri R, Dunne C, Broderick AM, Grant T, Hamzawi M, et al. Rapid rise in incidence of Irish paediatric inflammatory bowel disease. Arch Dis Child. (2012) 97:590-4. doi: 10.1136/archdischild-2011-300651

8. Henderson P, Hansen R, Cameron FL, Gerasimidis K, Rogers P, Bisset WM, et al. Rising incidence of pediatric inflammatory bowel disease in Scotland. Inflamm Bowel Dis. (2012) 18:999-1005. doi: 10.1002/ibd.21797

9. Martin-de-Carpi J, Rodriguez A, Ramos E, Jimenez S, Martinez-Gomez MJ, Medina E. Increasing incidence of pediatric inflammatory bowel disease in Spain (1996-2009): the SPIRIT Registry. Inflamm Bowel Dis. (2013) 19:73-80. doi: 10.1002/ibd.22980

10. Rigoli L, Caruso RA. Inflammatory bowel disease in pediatric and adolescent patients: a biomolecular and histopathological review. World J Gastroenterol. (2014) 20:10262-78. doi: 10.3748/wjg.v20.i30.10262

11. Gent AE, Hellier MD, Grace RH, Swarbrick ET, Coggon D. Inflammatory bowel disease and domestic hygiene in infancy. Lancet. (1994) 343:7667. doi: 10.1016/S0140-6736(94)91841-4

12. Radon K, Windstetter D, Poluda AL, Mueller B, von Mutius E, Koletzko S. Contact with farm animals in early life and juvenile inflammatory bowel disease: a case-control study. Pediatrics. (2007) 120:35461. doi: 10.1542/peds.2006-3624

13. Springmann V, Brassard P, Krupoves A, Amre D. Timing, frequency and type of physician-diagnosed infections in childhood and these approaches have undergone clinical investigation among adult IBD patients, more extensive pediatric cohort trials are necessary before an evaluation of their appropriateness for use in PIBD.

\section{AUTHOR CONTRIBUTIONS}

All authors listed have made a substantial, direct and intellectual contribution to the work, and approved it for publication.

\section{FUNDING}

PTW, SH, and AL were funded by the National Children's Research Centre, Dublin, Ireland. Award numbers: K/17/1 and G/19/2. SH was supported by National Childrens Research Centre; DOCHAS project J/15/1. risk for Crohn's disease in children and young adults. Inflamm Bowel Dis. (2014) 20:1346-52. doi: 10.1097/MIB.000000000000 0098

14. Comito D, Romano C. Dysbiosis in the pathogenesis of pediatric inflammatory bowel diseases. Int J Inflam. (2012) 2012:687143. doi: 10.1155/2012/687143

15. Jostins L, Ripke S, Weersma RK, Duerr RH, McGovern DP, Hui $\mathrm{KY}$, et al. Host-microbe interactions have shaped the genetic architecture of inflammatory bowel disease. Nature. (2012) 491:119-24. doi: 10.1038/nature11582

16. Aujnarain A, Mack DR, Benchimol EI. The role of the environment in the development of pediatric inflammatory bowel disease. Current Gastroenterol Rep. (2013) 15:326. doi: 10.1007/s11894-013-0326-4

17. Xu L, Lochhead P, Ko Y, Claggett B, Leong RW, Ananthakrishnan AN. Systematic review with meta-analysis: breastfeeding and the risk of Crohn's disease and ulcerative colitis. Aliment Pharmacol Ther. (2017) 46:7809. doi: 10.1111/apt.14291

18. Ortqvist AK, Lundholm C, Halfvarson J, Ludvigsson JF, Almqvist C. Fetal and early life antibiotics exposure and very early onset inflammatory bowel disease: a population-based study. Gut. (2019) 68:21825. doi: 10.1136/gutjnl-2017-314352

19. Gevers D, Kugathasan S, Denson LA, Vazquez-Baeza Y, Van Treuren $\mathrm{W}$, Ren B, et al. The treatment-naive microbiome in new-onset Crohn's disease. Cell Host Microbe. (2014) 15:382-92. doi: 10.1016/j.chom.2014. 02.005

20. Van Limbergen J, Russell RK, Drummond HE, Aldhous MC, Round NK, Nimmo ER, et al. Definition of phenotypic characteristics of childhoodonset inflammatory bowel disease. Gastroenterology. (2008) 135:111422. doi: 10.1053/j.gastro.2008.06.081

21. Abuquteish D, Putra J. Upper gastrointestinal tract involvement of pediatric inflammatory bowel disease: a pathological review. World J Gastroenterol. (2019) 25:1928-35. doi: 10.3748/wjg.v25.i16.1928

22. Wilson DC, Russell RK. Overview of paediatric IBD. Semin Pediatr Surg. (2017) 26:344-8. doi: 10.1053/j.sempedsurg.2017.10.002

23. Guariso G, Gasparetto M. Treating children with inflammatory bowel disease: current and new perspectives. World J Gastroenterol. (2017) 23:5469-85. doi: 10.3748/wjg.v23.i30.5469

24. Moeeni V, Day AS. Impact of inflammatory bowel disease upon growth in children and adolescents. ISRN Pediatr. (2011) 2011:365712. doi: 10.5402/2011/365712

25. Heikenen JB, Werlin SL, Brown CW, Balint JP. Presenting symptoms and diagnostic lag in children with inflammatory bowel disease. Inflamm Bowel Dis. (1999) 5:158-60. doi: 10.1097/00054725-199908000-00002

26. Spray C, Debelle GD, Murphy MS. Current diagnosis, management and morbidity in paediatric inflammatory bowel disease. Acta Paediatr. (2001) 90:400-5. doi: 10.1111/j.1651-2227.2001.tb00439.x 
27. Veereman-Wauters G, de Ridder L, Veres G, Kolacek S, Fell J, Malmborg $\mathrm{P}$, et al. Risk of infection and prevention in pediatric patients with IBD: ESPGHAN IBD Porto Group commentary. J Pediatr Gastroenterol Nutr. (2012) 54:830-7. doi: 10.1097/MPG.0b013e31824d1438

28. de Ridder L, Turner D, Wilson DC, Koletzko S, Martin-de-Carpi J, Fagerberg UL, et al. Malignancy and mortality in pediatric patients with inflammatory bowel disease: a multinational study from the porto pediatric IBD group. Inflamm Bowel Dis. (2014) 20:291-300. doi: 10.1097/01.MIB.0000439066.69340.3c

29. Olen O, Askling J, Sachs MC, Frumento P, Neovius M, Smedby $\mathrm{KE}$, et al. Childhood onset inflammatory bowel disease and risk of cancer: a Swedish nationwide cohort study 1964-2014. BMJ. (2017) 358:j3951. doi: 10.1136/bmj.j3951

30. Joosse ME, Aardoom MA, Kemos P, Turner D, Wilson DC, Koletzko S, et al. Malignancy and mortality in paediatric-onset inflammatory bowel disease: a 3-year prospective, multinational study from the paediatric IBD Porto group of ESPGHAN. Aliment Pharmacol Ther. (2018) 48:52337. doi: 10.1111/apt.14893

31. Malham M, Jakobsen C, Paerregaard A, Virta LJ, Kolho KL, Wewer V. The incidence of cancer and mortality in paediatric onset inflammatory bowel disease in Denmark and Finland during a 23-year period: a population-based study. Aliment Pharmacol Ther. (2019) 50:33-9. doi: 10.1111/apt.15258

32. Olen O, Askling J, Sachs MC, Frumento P, Neovius M, Smedby KE, et al. Increased mortality of patients with childhood-onset inflammatory bowel diseases, compared with the general population. Gastroenterology. (2019) 156:614-22. doi: 10.1053/j.gastro.2018.10.028

33. Artis D. Epithelial-cell recognition of commensal bacteria and maintenance of immune homeostasis in the gut. Nat Rev Immunol. (2008) 8:41120. doi: $10.1038 /$ nri2316

34. Meinzer U, Ideström M, Alberti C, Peuchmaur M, Belarbi N, Bellaïche M, et al. Ileal involvement is age dependent in pediatric Crohn's disease. Inflamm Bowel Dis. (2005) 11:639-44. doi: 10.1097/01.MIB.0000165114.10687.bf

35. Harrison OJ, Powrie FM. Regulatory $T$ cells and immune tolerance in the intestine. Cold Spring Harb Perspect Biol. (2013) 5:a018341. doi: 10.1101/cshperspect.a018341

36. Cosovanu C, Neumann C. The many functions of Foxp3(+) regulatory $\mathrm{T}$ Cells in the intestine. Front Immunol. (2020) 11:600973. doi: 10.3389/fimmu.2020.600973

37. Bennett CL, Christie J, Ramsdell F, Brunkow ME, Ferguson PJ, Whitesell $\mathrm{L}$, et al. The immune dysregulation, polyendocrinopathy, enteropathy, Xlinked syndrome (IPEX) is caused by mutations of FOXP3. Nat Genet. (2001) 27:20-1. doi: 10.1038/83713

38. Wildin RS, Smyk-Pearson S, Filipovich AH. Clinical and molecular features of the immunodysregulation, polyendocrinopathy, enteropathy, $\mathrm{X}$ linked (IPEX) syndrome. J Med Genet. (2002) 39:537-45. doi: 10.1136/jmg.39.8.537

39. Zhan H, Sinclair J, Adams S, Cale CM, Murch S, Perroni L, et al. Immune reconstitution and recovery of FOXP3 (forkhead box P3)expressing $\mathrm{T}$ cells after transplantation for IPEX (immune dysregulation, polyendocrinopathy, enteropathy, X-linked) syndrome. Pediatrics. (2008) 121:e998-1002. doi: 10.1542/peds.2007-1863

40. Zhu XM, Shi YZ, Cheng M, Wang DF, Fan JF. Serum IL-6, IL23 profile and Treg/Th17 peripheral cell populations in pediatric patients with inflammatory bowel disease. Pharmazie. (2017) 72:283-7. doi: 10.1691/ph.2017.6957

41. Ricciardelli I, Lindley KJ, Londei M, Quaratino S. Anti tumour necrosisalpha therapy increases the number of FOXP3 regulatory $\mathrm{T}$ cells in children affected by Crohn's disease. Immunology. (2008) 125:17883. doi: 10.1111/j.1365-2567.2008.02839.x

42. Hyun J, Oh J, Seo J, Cho MS, Cho Y, Sun E, et al. FOXP3+T Cells and TGF$\beta 1$ in colonic mucosa of children with crohn's disease. Korean J Pediatric Gastroenterol Nutrition. (2011) 14:258-68. doi: 10.5223/kjpgn.2011. 14.3.258

43. Cho J, Kim S, Yang DH, Lee J, Park KW, Go J, et al. Mucosal immunity related to FOXP3(+) regulatory T cells, Th17 cells and cytokines in pediatric inflammatory bowel disease. J Korean Med Sci. (2018) 33:e336. doi: 10.3346/jkms.2018.33.e336

44. Reikvam DH, Perminow G, Lyckander LG, Gran JM, Brandtzaeg P, Vatn $\mathrm{M}$, et al. Increase of regulatory $\mathrm{T}$ cells in ileal mucosa of untreated pediatric Crohn's disease patients. Scand J Gastroenterol. (2011) 46:55060. doi: 10.3109/00365521.2011.551887

45. La Scaleia R, Morrone S, Stoppacciaro A, Scarpino S, Antonelli M, Bianchi E, et al. Peripheral and intestinal CD4 $+\mathrm{T}$ cells with a regulatory phenotype in pediatric patients with inflammatory bowel disease. J Pediatr Gastroenterol Nutr. (2010) 51:563-72. doi: 10.1097/MPG.0b013e3181e4d323

46. Hölttä V, Klemetti P, Salo HM, Koivusalo A, Pakarinen M, WesterholmOrmio $\mathrm{M}$, et al. Interleukin-17 immunity in pediatric Crohn disease and ulcerative colitis. J Pediatr Gastroenterol Nutr. (2013) 57:28792. doi: 10.1097/MPG.0b013e3182979252

47. Joosse ME, Menckeberg CL, de Ruiter LF, Raatgeep HRC, van Berkel LA, Simons-Oosterhuis Y, et al. Frequencies of circulating regulatory TIGIT $(+) \mathrm{CD} 38(+)$ effector $\mathrm{T}$ cells correlate with the course of inflammatory bowel disease. Mucosal Immunol. (2019) 12:154-63. doi: 10.1038/s41385-018-0078-4

48. Imielinski M, Baldassano RN, Griffiths A, Russell RK, Annese V, Dubinsky $\mathrm{M}$, et al. Common variants at five new loci associated with early-onset inflammatory bowel disease. Nat Genet. (2009) 41:133540. doi: 10.1038/ng.489

49. Wang H, Meng R, Li Z, Yang B, Liu Y, Huang F, et al. IL-27 induces the differentiation of Tr1-like cells from human naive CD4+ T cells via the phosphorylation of STAT1 and STAT3. Immunol Lett. (2011) 136:218. doi: 10.1016/j.imlet.2010.11.007

50. Shen X, Du J, Guan W, Zhao Y. The balance of intestinal Foxp3+ regulatory $\mathrm{T}$ cells and Th17 cells and its biological significance. Expert Rev Clin Immunol. (2014) 10:353-62. doi: 10.1586/1744666X.2014.882232

51. Hueber W, Sands BE, Lewitzky S, Vandemeulebroecke M, Reinisch W, Higgins PD, et al. Secukinumab, a human anti-IL-17A monoclonal antibody, for moderate to severe Crohn's disease: unexpected results of a randomised, double-blind placebo-controlled trial. Gut. (2012) 61:1693700. doi: 10.1136/gutjnl-2011-301668

52. Krawiec P, Pac-Kozuchowska E. Serum interleukin 17A and interleukin $17 \mathrm{~F}$ in children with inflammatory bowel disease. Scientific Reports. (2020) 10:12617. doi: 10.1038/s41598-020-69567-x

53. Fuss IJ, Neurath M, Boirivant M, Klein JS, de la Motte C, Strong $\mathrm{SA}$, et al. Disparate CD4+ lamina propria (LP) lymphokine secretion profiles in inflammatory bowel disease. Crohn's disease LP cells manifest increased secretion of IFN-gamma, whereas ulcerative colitis LP cells manifest increased secretion of IL-5. J Immunol. (1996) 157:126170. doi: 10.1097/00024382-199703001-00528

54. Muzes G, Molnar B, Tulassay Z, Sipos F. Changes of the cytokine profile in inflammatory bowel diseases. World J Gastroenterol. (2012) 18:584861. doi: 10.3748/wjg.v18.i41.5848

55. Breese E, Braegger CP, Corrigan CJ, Walker-Smith JA, MacDonald TInterleukin-2- $\mathrm{T}$, and interferon-gamma-secreting $\mathrm{T}$ cells in normal and diseased human intestinal mucosa. Immunology. (1993) 78:127-31.

56. Mullin GE, Maycon ZR, Braun-Elwert L, Cerchia R, James SP, Katz S, et al. Inflammatory bowel disease mucosal biopsies have specialized lymphokine mRNA profiles. Inflamm Bowel Dis. (1996) 2:16-26. doi: 10.1097/00054725-199603000-00004

57. Ohtani K, Ohtsuka Y, Ikuse T, Baba Y, Yamakawa Y, Aoyagi Y, et al. Increased mucosal expression of GATA-3 and STAT-4 in pediatric ulcerative colitis. Pediatr Int. (2010) 52:584-9. doi: 10.1111/j.1442-200X.2009.03019.x

58. Holland N, Dong J, Garnett E, Shaikh N, Huen K, Harmatz P, et al. Reduced intracellular T-helper 1 interferon-gamma in blood of newly diagnosed children with Crohn's disease and age-related changes in Th1/Th2 cytokine profiles. Pediatr Res. (2008) 63:257-62. doi: 10.1203/PDR.0b013e318163a897

59. Smart JM, Kemp AS. Ontogeny of T-helper 1 and T-helper 2 cytokine production in childhood. Pediatr Allergy Immunol. (2001) 12:1817. doi: 10.1034/j.1399-3038.2001.012004181.x

60. Hartel C, Adam N, Strunk T, Temming P, Muller-Steinhardt M, Schultz C. Cytokine responses correlate differentially with age in infancy and early childhood. Clin Exp Immunol. (2005) 142:44653. doi: 10.1111/j.1365-2249.2005.02928.x

61. Gerlach K, Hwang Y, Nikolaev A, Atreya R, Dornhoff H, Steiner S, et al. TH9 cells that express the transcription factor PU.1 drive T cell-mediated colitis via IL-9 receptor signaling in intestinal epithelial cells. Nat Immunol. (2014) 15:676-86. doi: $10.1038 /$ ni. 2920 
62. Hepworth MR, Fung TC, Masur SH, Kelsen JR, McConnell FM, Dubrot J, et al. Immune tolerance. Group 3 innate lymphoid cells mediate intestinal selection of commensal bacteria-specific CD4(+) T cells. Science. (2015) 348:1031-5. doi: 10.1126/science.aaa4812

63. Huang B, Chen Z, Geng L, Wang J, Liang H, Cao Y, et al. Mucosal profiling of pediatric-onset colitis and IBD reveals common pathogenics and therapeutic pathways. Cell. (2019) 179:1160-76.e1124. doi: 10.1016/j.cell.2019.10.027

64. Rabe H, Malmquist M, Barkman C, Östman S, Gjertsson I. Saalman R, et al. Distinct patterns of naive, activated and memory $\mathrm{T}$ and $\mathrm{B}$ cells in blood of patients with ulcerative colitis or Crohn's disease. Clin Exp Immunol. (2019) 197:111-29. doi: 10.1111/cei.13294

65. McCarthy NE, Hedin CR, Sanders TJ, Amon P, Hoti I, Ayada I, et al. Azathioprine therapy selectively ablates human V $\delta 2$ ? T cells in Crohn's disease. J Clin Invest. (2015) 125:3215-25. doi: 10.1172/JCI80840

66. Ley K, Laudanna C, Cybulsky MI, Nourshargh S. Getting to the site of inflammation: the leukocyte adhesion cascade updated. Nat Rev Immunol. (2007) 7:678-89. doi: 10.1038/nri2156

67. Marsal J, Agace WW. Targeting T-cell migration in inflammatory bowel disease. J Intern Med. (2012) 272:41129. doi: 10.1111/j.1365-2796.2012.02588.x

68. von Andrian UH, Mackay CR. T-cell function and migration. Two sides of the same coin. N Engl J Med. (2000) 343:102034. doi: 10.1056/NEJM200010053431407

69. von Andrian UH, Mempel TR. Homing and cellular traffic in lymph nodes. Nat Rev Immunol. (2003) 3:867-78. doi: 10.1038/nri1222

70. Agace WW. T-cell recruitment to the intestinal mucosa. Trends Immunol. (2008) 29:514-22. doi: 10.1016/j.it.2008.08.003

71. Mora JR. Homing imprinting and immunomodulation in the gut: role of dendritic cells and retinoids. Inflamm Bowel Dis. (2008) 14:27589. doi: $10.1002 /$ ibd. 20280

72. Koboziev I, Karlsson F, Grisham MB. Gut-associated lymphoid tissue, T cell trafficking, and chronic intestinal inflammation. Ann N Y Acad Sci. (2010) 1207(Suppl. 1):E86-93. doi: 10.1111/j.1749-6632.2010.05711.x

73. Luster $\mathrm{AD}$, Alon $\mathrm{R}$, von Andrian. U. H. Immune cell migration in inflammation: present and future therapeutic targets. Nat Immunol. (2005) 6:1182-90. doi: 10.1038/ni1275

74. Laufer JM, Legler DF. Beyond migration-Chemokines in lymphocyte priming, differentiation, and modulating effector functions. J Leukoc Biol. (2018) 104:301-12. doi: 10.1002/JLB.2MR1217-494R

75. Uhlig HH, Powrie F. The role of mucosal T lymphocytes in regulating intestinal inflammation. Springer Semin Immunopathol. (2005) 27:16780. doi: 10.1007/s00281-005-0206-6

76. Coombes JL, Siddiqui KR, Arancibia-Carcamo CV, Hall J, Sun CM, Belkaid Y, et al. A functionally specialized population of mucosal CD103+ DCs induces Foxp3+ regulatory $\mathrm{T}$ cells via a TGF-beta and retinoic acid-dependent mechanism. J Exp Med. (2007) 204:1757-64. doi: 10.1084/jem.20070590

77. Jaensson E, Uronen-Hansson H, Pabst O, Eksteen B, Tian J, Coombes JL, et al. Small intestinal CD103+ dendritic cells display unique functional properties that are conserved between mice and humans. J Exp Med. (2008) 205:2139-49. doi: 10.1084/jem.20080414

78. Blomhoff R, Blomhoff HK. Overview of retinoid metabolism and function. $J$ Neurobiol. (2006) 66:606-30. doi: 10.1002/neu.20242

79. Uematsu S, Fujimoto K, Jang MH, Yang BG, Jung YJ, Nishiyama M, et al. Regulation of humoral and cellular gut immunity by lamina propria dendritic cells expressing Toll-like receptor 5. Nat Immunol. (2008) 9:76976. doi: 10.1038/ni.1622

80. Iwata M, Hirakiyama A, Eshima Y, Kagechika H, Kato C, Song SY. Retinoic acid imprints gut-homing specificity on T cells. Immunity. (2004) 21:52738. doi: 10.1016/j.immuni.2004.08.011

81. Mora JR, Iwata M, Eksteen B, Song SY, Junt T, Senman B, et al. Generation of gut-homing IgA-secreting B cells by intestinal dendritic cells. Science. (2006) 314:1157-60. doi: 10.1126/science.1132742

82. Lampen A, Meyer S, Arnhold T, Nau H. Metabolism of vitamin A and its active metabolite all-trans-retinoic acid in small intestinal enterocytes. $J$ Pharmacol Exp Ther. (2000) 295:979-85.

83. Tokuyama H, Tokuyama Y. Retinoic acid induces the expression of germline C alpha transcript mainly by a TGF-beta-independent mechanism. Cell Immunol. (1997) 176:14-21. doi: 10.1006/cimm.1996.1069
84. Lee JH, Kang SG, Kim CH. FoxP3 + T cells undergo conventional first switch to lymphoid tissue homing receptors in thymus but accelerated second switch to nonlymphoid tissue homing receptors in secondary lymphoid tissues. J Immunol. (2007) 178:301-11. doi: 10.4049/jimmunol.178.1.301

85. Siewert C, Menning A, Dudda J, Siegmund K, Lauer U, Floess S, et al. Induction of organ-selective CD4+ regulatory T cell homing. Eur J Immunol. (2007) 37:978-89. doi: 10.1002/eji.200636575

86. Fu S, Yopp AC, Mao X, Chen D, Zhang N, Chen D, et al. CD4+ CD25+ CD62+ T-regulatory cell subset has optimal suppressive and proliferative potential. Am J Transplant. (2004) 4:65-78. doi: 10.1046/j.1600-6143.2003.00293.x

87. Denning TL, Kim G, Kronenberg M. Cutting edge: CD4+CD25+ regulatory T cells impaired for intestinal homing can prevent colitis. J Immunol. (2005) 174:7487-91. doi: 10.4049/jimmunol.174.12.7487

88. Schneider MA, Meingassner JG, Lipp M, Moore HD, Rot A. CCR7 is required for the in vivo function of CD4+ CD25+ regulatory T cells. J Exp Med. (2007) 204:735-45. doi: 10.1084/jem.20061405

89. Arihiro S, Ohtani H, Suzuki M, Murata M, Ejima C, Oki M, et al. Differential expression of mucosal addressin cell adhesion molecule-1 (MAdCAM1) in ulcerative colitis and Crohn's disease. Pathol Int. (2002) 52:36774. doi: 10.1046/j.1440-1827.2002.01365.x

90. Ericsson A, Svensson M, Arya A, Agace WW. CCL25/CCR9 promotes the induction and function of CD103 on intestinal intraepithelial lymphocytes. Eur J Immunol. (2004) 34:2720-9. doi: 10.1002/eji.200425125

91. Cheroutre H, Lambolez F, Mucida D. The light and dark sides of intestinal intraepithelial lymphocytes. Nat Rev Immunol. (2011) 11:44556. doi: 10.1038/nri3007

92. Lefrancois L, Parker CM, Olson S, Muller W, Wagner N, Schon MP, et al. The role of beta7 integrins in CD8 $\mathrm{T}$ cell trafficking during an antiviral immune response. J Exp Med. (1999) 189:1631-8. doi: 10.1084/jem.189.10.1631

93. Papadakis KA, Prehn J, Nelson V, Cheng L, Binder SW, Ponath PD, et al. The role of thymus-expressed chemokine and its receptor CCR9 on lymphocytes in the regional specialization of the mucosal immune system. J Immunol. (2000) 165:5069-76. doi: 10.4049/jimmunol.165.9.5069

94. Stenstad H, Svensson M, Cucak H, Kotarsky K, Agace WW. Differential homing mechanisms regulate regionalized effector CD8alphabeta $+\mathrm{T}$ cell accumulation within the small intestine. Proc Natl Acad Sci USA. (2007) 104:10122-7. doi: 10.1073/pnas.0700269104

95. Oyama T, Miura S, Watanabe C, Hokari R, Fujiyama Y, Komoto S, et al. CXCL12 and CCL20 play a significant role in mucosal T-lymphocyte adherence to intestinal microvessels in mice. Microcirculation. (2007) 14:753-66. doi: 10.1080/10739680701409993

96. McDermott MR, Mark DA, Befus AD, Baliga BS, Suskind RM, Bienenstock J. Impaired intestinal localization of mesenteric lymphoblasts associated with vitamin A deficiency and protein-calorie malnutrition. Immunology. (1982) 45:1-5.

97. Nguyen LP, Pan J, Dinh TT, Hadeiba H, O’Hara, 3rd E, Ebtikar A, et al. Role and species-specific expression of colon T cell homing receptor GPR15 in colitis. Nat Immunol. (2015) 16:207-13. doi: 10.1038/ni.3079

98. Fischer A, Zundler S, Atreya R, Rath T, Voskens C, Hirschmann S, et al. Differential effects of alpha4beta7 and GPR15 on homing of effector and regulatory T cells from patients with UC to the inflamed gut in vivo. Gut. (2016) 65:1642-64. doi: 10.1136/gutjnl-2015-310022

99. Adamczyk A, Gageik D, Frede A, Pastille E, Hansen W, Rueffer A, et al. Differential expression of GPR15 on T cells during ulcerative colitis. JCI Insight. (2017) 2:e90585. doi: 10.1172/jci.insight.90585

100. Trivedi PJ, Bruns T, Ward S, Mai M, Schmidt C, Hirschfield GM, et al. Intestinal CCL25 expression is increased in colitis and correlates with inflammatory activity. J Autoimmun. (2016) 68:98-104. doi: 10.1016/j.jaut.2016.01.001

101. Wurbel MA, McIntire MG, Dwyer P, Fiebiger E. CCL25/CCR9 interactions regulate large intestinal inflammation in a murine model of acute colitis. PLoS ONE. (2011) 6:e16442. doi: 10.1371/journal.pone.0016442

102. Hamann A, Andrew DP, Jablonski-Westrich D, Holzmann B, Butcher EC. Role of alpha 4-integrins in lymphocyte homing to mucosal tissues in vivo.J Immunol. (1994) 152:3282-93.

103. Wagner N, Lohler J, Kunkel EJ, Ley K, Leung E, Krissansen G, et al. Critical role for beta7 integrins in formation of the gut-associated 
lymphoid tissue. Nature. (1996) 382:366-70. doi: $10.1038 / 3823$ $66 \mathrm{a} 0$

104. Gorfu G, Rivera-Nieves J, Hoang S, Abbott DW, Arbenz-Smith K, Azar DW, et al. Beta7 integrin deficiency suppresses B cell homing and attenuates chronic ileitis in SAMP1/YitFc mice. J Immunol. (2010) 185:55618. doi: 10.4049/jimmunol.0903938

105. Wurbel MA, Malissen M, Guy-Grand D, Malissen B, Campbell JJ. Impaired accumulation of antigen-specific CD8 lymphocytes in chemokine CCL25deficient intestinal epithelium and lamina propria. J Immunol. (2007) 178:7598-606. doi: 10.4049/jimmunol.178.12.7598

106. Trivedi PJ, Adams DH. Chemokines and chemokine receptors as therapeutic targets in inflammatory bowel disease; pitfalls and promise. J Crohns Colitis. (2018) 12:S641-52. doi: 10.1093/ecco-jcc/jjy130

107. Schroepf S, Kappler R, Brand S, Prell C, Lohse P, Glas J, et al. Strong overexpression of CXCR3 axis components in childhood inflammatory bowel disease. Inflamm Bowel Dis. (2010) 16:1882-90. doi: 10.1002/ibd.21312

108. Kaser A, Ludwiczek O, Holzmann S, Moschen AR, Weiss G, Enrich B, et al. Increased expression of CCL20 in human inflammatory bowel disease. J Clin Immunol. (2004) 24:74-85. doi: 10.1023/B:JOCI.0000018066.46279.6b

109. Teramoto K, Miura S, Tsuzuki Y, Hokari R, Watanabe C, Inamura $\mathrm{T}$, et al. Increased lymphocyte trafficking to colonic microvessels is dependent on MAdCAM-1 and C-C chemokine mLARC/CCL20 in DSS-induced mice colitis. Clin Exp Immunol. (2005) 139:421-8. doi: 10.1111/j.1365-2249.2004.02716.x

110. Gasparetto M, Guariso G. Crohn's disease and growth deficiency in children and adolescents. World J Gastroenterol. (2014) 20:1321933. doi: 10.3748/wjg.v20.i37.13219

111. Bartelink IH, Rademaker CM, Schobben AF, van den Anker JN. Guidelines on paediatric dosing on the basis of developmental physiology and pharmacokinetic considerations. Clin Pharmacokinet. (2006) 45:107797. doi: 10.2165/00003088-200645110-00003

112. Vinks AA, Emoto C, Fukuda T. Modeling and simulation in pediatric drug therapy: Application of pharmacometrics to define the right dose for children. Clin Pharmacol Ther. (2015) 98:298-308. doi: 10.1002/cpt.169

113. Ruemmele FM, Veres G, Kolho KL, Griffiths A, Levine A, Escher JC, et al. Consensus guidelines of ECCO/ESPGHAN on the medical management of pediatric Crohn's disease. J Crohns Colitis. (2014) 8:1179207. doi: 10.1016/j.crohns.2014.04.005

114. Baert FJ, D’Haens GR, Peeters M, Hiele MI, Schaible TF, Shealy D, et al. Tumor necrosis factor $\alpha$ antibody (infliximab) therapy profoundly downregulates the inflammation in Crohn's ileocolitis. Gastroenterology. (1999) 116:22-8. doi: 10.1016/S0016-5085(99)70224-6

115. Ransohoff RM. Natalizumab for multiple sclerosis. N Engl J Med. (2007) 356:2622-9. doi: 10.1056/NEJMct071462

116. Bellaguarda E, Keyashian K, Pekow J, Rubin DT, Cohen RD, Sakuraba A. Prevalence of antibodies against JC virus in patients with refractory crohn's disease and effects of natalizumab therapy. Clin Gastroenterol Hepatol. (2015) 13:1919-25. doi: 10.1016/j.cgh.2015.05.022

117. Schreiber S, Dignass A, Peyrin-Biroulet L, Hather G, Demuth D, Mosli M, et al. Systematic review with meta-analysis: real-world effectiveness and safety of vedolizumab in patients with inflammatory bowel disease. J Gastroenterol. (2018) 53:1048-64. doi: 10.1007/s00535-018-1480-0

118. Colombel JF, Sands BE, Rutgeerts P, Sandborn W, Danese S, D'Haens G, et al. The safety of vedolizumab for ulcerative colitis and Crohn's disease. Gut. (2017) 66:839-51. doi: 10.1136/gutjnl-2015-311079

119. Hyams JS, Wilson DC, Thomas A, Heuschkel R, Mitton S, Mitchell B, et al. Natalizumab therapy for moderate to severe Crohn disease in adolescents. J Pediatr Gastroenterol Nutr. (2007) 44:185-91. doi: 10.1097/01.mpg.0000252191.05170.e7

120. Singh N, Rabizadeh S, Jossen J, Pittman N, Check M, Hashemi $\mathrm{G}$, et al. Multi-center experience of vedolizumab effectiveness in pediatric inflammatory bowel disease. Inflamm Bowel Dis. (2016) 22:2121-6. doi: 10.1097/MIB.0000000000000865

121. Schneider AM, Weghuber D, Hetzer B, Entenmann A, Muller T, Zimmermann G, et al. Vedolizumab use after failure of TNF-alpha antagonists in children and adolescents with inflammatory bowel disease. BMC Gastroenterol. (2018) 18:140. doi: 10.1186/s12876-018-0868-x

122. Sandborn WJ, Cyrille M, Hansen MB, Feagan BG, Loftus EV, Vermeire S, et al. Efficacy and safety of abrilumab (AMG 181/MEDI 7183) therapy for moderate to severe Crohn's disease. J Crohns Colitis. (2017) 11:S223. doi: 10.1093/ecco-jcc/jjx002.034

123. Sandborn WJ, Cyrille M, Hansen MB, Feagan BG, Loftus, E. V. Jr., et al. Efficacy and safety of abrilumab in a randomized, placebo-controlled trial for moderate-to-severe ulcerative colitis. Gastroenterology. (2019) 156:946-57 e918. doi: 10.1053/j.gastro.2018.11.035

124. Tew GW, Hackney JA, Gibbons D, Lamb CA, Luca D, Egen JG, et al. Association between response to etrolizumab and expression of integrin alphaE and granzyme A in colon biopsies of patients with ulcerative colitis. Gastroenterology. (2016) 150:477-87 e479. doi: 10.1053/j.gastro.2015.10.041

125. Rutgeerts PJ, Fedorak RN, Hommes DW, Sturm A, Baumgart DC, Bressler B, et al. A randomised phase I study of etrolizumab (rhuMAb beta7) in moderate to severe ulcerative colitis. Gut. (2013) 62:112230. doi: 10.1136/gutjnl-2011-301769

126. Vermeire S, O’Byrne S, Keir M, Williams M, Lu TT, Mansfield JC, et al. Etrolizumab as induction therapy for ulcerative colitis: a randomised, controlled, phase 2 trial. Lancet. (2014) 384:309-18. doi: 10.1016/S0140-6736(14)60661-9

127. Yacyshyn B, Chey WY, Wedel MK, Yu RZ, Paul D, Chuang E. A randomized, double-masked, placebo-controlled study of alicaforsen, an antisense inhibitor of intercellular adhesion molecule 1, for the treatment of subjects with active Crohn's disease. Clin Gastroenterol Hepatol. (2007) 5:215-20. doi: 10.1016/j.cgh.2006.11.001

128. Greuter T, Vavricka SR, Biedermann L, Pilz J, Borovicka J, Seibold F, et al. Alicaforsen, an antisense inhibitor of intercellular adhesion molecule-1, in the treatment for left-sided ulcerative colitis and ulcerative proctitis. Dig Dis. (2018) 36:123-9. doi: 10.1159/000484979

129. Keshav S, Vanasek T, Niv Y, Petryka R, Howaldt S, Bafutto M, et al. A randomized controlled trial of the efficacy and safety of CCX282-B, an orallyadministered blocker of chemokine receptor CCR9, for patients with Crohn's disease. PLoS ONE. (2013) 8:e60094. doi: 10.1371/journal.pone.0060094

130. Feagan BG, Sandborn WJ, D’Haens G, Lee SD, Allez M, Fedorak RN, et al. Randomised clinical trial: vercirnon, an oral CCR9 antagonist, vs. placebo as induction therapy in active Crohn's disease. Aliment Pharmacol Ther. (2015) 42:1170-81. doi: 10.1111/apt.13398

131. Vermeire S, Sandborn WJ, Danese S, Hebuterne X, Salzberg BA, Klopocka $\mathrm{M}$, et al. Anti-MAdCAM antibody (PF-00547659) for ulcerative colitis (TURANDOT): a phase 2, randomised, double-blind, placebo-controlled trial. Lancet. (2017) 390:135-44. doi: 10.1016/S0140-6736(17)30930-3

132. Sandborn WJ, Feagan BG, Wolf DC, D'Haens G, Vermeire S, Hanauer SB, et al. Ozanimod induction and maintenance treatment for ulcerative colitis. $N$ Engl J Med. (2016) 374:1754-62. doi: 10.1056/NEJMoa1513248

Conflict of Interest: The authors declare that the research was conducted in the absence of any commercial or financial relationships that could be construed as a potential conflict of interest.

Copyright (๑) 2021 Giannoudaki, Gargan, Hussey, Long and Walsh. This is an openaccess article distributed under the terms of the Creative Commons Attribution License (CC BY). The use, distribution or reproduction in other forums is permitted, provided the original author(s) and the copyright owner(s) are credited and that the original publication in this journal is cited, in accordance with accepted academic practice. No use, distribution or reproduction is permitted which does not comply with these terms. 